\begin{tabular}{|c|c|c|}
\hline $\begin{array}{l}\text { FATIH } \\
\text { SULTAN } \\
\text { MEHMET } \\
\text { vAKK UNIIVERSITESi } \\
2010\end{array}$ & $\begin{array}{l}\text { FSM İlmî Araştırmalar Insan ve Toplum Bilimleri Dergisi } \\
\text { FSM Scholarly Studies Journal of Humanities and Social Sciences } \\
\text { Sayı/Number } 9 \text { Yıl/Year } 2017 \text { Bahar/Spring } \\
\text { c } 2017 \text { Fatih Sultan Mehmet Vakıf Üniversitesi }\end{array}$ & 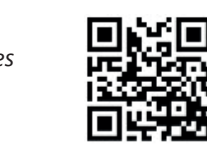 \\
\hline - & http://dergipark.gov.tr/fsmia - & http://dergi.fsm.edu.tr \\
\hline
\end{tabular}

\title{
15 Temmuz Hakkında Yazılmış Hikâyelerden Güray Süngü'nün “Gece” sini Tahlil Denemesi
}

\author{
Sevim Zehra Can Kaya*
}

\section{Öz}

15 Temmuz 2016 tarihinde Türkiye'de gerçekleștirilen darbe teşebbüsü ardından, darbe girişimini konu alan bir çok hikâye yazılmıştır. Bu hikâyelerinden Güray Süngü'nün "Gece" adlı hikâyesi özgün bir niteliğe sahiptir. Kesit hikâye türünde yazılmış olan "Gece", 15 Temmuz darbe teşebbüsünün ilk saatlerini ele alır. Ana karakterin bakış açısıyla, darbe teşebbüsü karşısında Türk halkının gösterdiği direnişin ilk anları aktarılır.

Anahtar Kelimeler: 15 Temmuz darbe teşebbüsü, kesit hikâyesi, Güray Süngü, Gece.

\section{An Analysis of Güray Süngü's "Gece" One of the Original Stories Written About the 15 July Coup Attempt}

\section{Abstract}

After the 15 July 2016 coup attempt in Turkey many stories were written about it. One of those stories is Güray Süngü's "Gece" which is an original one among those stories. Written as a situation story "Gece" deals with the early hours of the 15 July coup attempt. The first moments of the resistance of Turkish people against the coup attempt is explained from the main character's perspective.

Keywords: 15 July coup attempt, situation story, Güray Süngü, Gece.

* Doktora Öğrencisi, Fatih Sultan Mehmet Vakıf Üniversitesi Sosyal Bilimler Enstitüsü Türk Dili ve Edebiyatı Anabilim Dalı, İstanbul/Türkiye, szehrakaya1@gmail.com 


\section{Giriş}

İğne deliğine veya bir kum tanesine heykeller oyan sanatkârlar, küçüklük ve büyüklüğe dair genel geçer anlamları sorgulatacak işler çıkarırlar. Çıplak gözle görülemeyecek kadar küçük yüzeylerde inşa edilen bir sanat eseri görüldükten sonra, artık onu görmeden evvelki gibi düşünülemez. Hayatın diğer katmanlarında, küçük yahut büyük diye vasıflandırılan her şeyin yeniden gözden geçirilmesi kuvvetle muhtemeldir.

Yüzeye nispetle iğne deliği, çöle nispetle bir kum tanesi neyse, zamana nispetle bir an da öyledir. Bu noktadan hareketle düşünüldügünde, başarılı bir hikâye yazarının da anı veya kısa bir zamanda olanları hikâyeleştirerek, okuyucusu üzerinde benzer, sarsıcı bir etki yaratabileceği ön görülebilir. Hikâyesinde küçük bir zaman dilimini derinlemesine ele alan yazar, o anın esasen ne büyük değişim ve dönüşümler barındırdığını gösterebilme kapasitesine sahiptir çünkü. Saniyelik vakitlerde ne denli derin kavrayışların yaşanabildiğini, çarpıcı bir ustalıkla okuyucusunun muhayyilesine sunar.

“Öykü genelde ... tüm olmuş bitmişleri temsil edecek bir anıyı, bir durumu anlatır. ... Öyküde bir hayat değil, hayatın küçük bir kesiti aktarılır. Ama bu kesitten bütün bir hayatı kestirebiliriz. Zaten iyi öyküler, hayatın kristalize olmuş bir ayrıntısını gün yüzüne çıkartıp hayatı temsil eden büyük bir fotoğraf hâline getirir." Öykünün yapısı gereği kısalığından istifade edilebilmektedir. Bu durum, kesit hikâyesi olarak adlandırılan alt türde daha bir belirginleşir. Kesit hikâyede, ayrıntılarla örülmüş kristalize bir anda hayatın heykelini çıkarmak benzeri bir sanat icra olunur.

Güray Süngü de "Gece"2sinde aslında böylesi bir anıtlaştırma etkisi oluşturmuştur. Hikâyesi kısadır, evet. Ve fakat vurucudur, özdür. Zaten Süngü’ye göre hikâye, kısa bir tür olduğu için az ama aynı zamanda öz yazılması gerekli bir metindir ${ }^{3}$. "Gece" yi de bu anlayışı doğrultusunda kurgular. Böylelikle kısa cümleler ve sade bir anlatım ile kurduğu hikâye yapısı ile Süngü, ele aldığı meselenin özünü yakalar ve parlatır.

15 Temmuz 2016 gecesi Türkiye Cumhuriyeti silahlı kuvvetleri içindeki illegal bir grubun gerçekleştirdiği darbe ve işgal teşebbüsüne ait küçük bir anın hikâyesidir "Gece". "Kısa kısa cümlelerle basit dile yaslanan anlatım" 1 sayesinde

1 Necip Tosun, “Karakter: Yeni Bir Hayat Teklifi”, Modern Öykü Kuramı, Hece Yayınları, İstanbul 2014, s. 116-117.

2 Güray Süngü, "Gece”, İtibar, S. 59, s. 52. (İncelediğimiz hikaye metni, tek sayfalık olduğundan çalışmamızın ilerleyen kısımlarında yapacağımız alıntılarda sayfa numarası belirtmeyeceğiz.)

3 Ali Ayçil, "Roman İnsanlığın Ortak Dili”, Dergâh, S.322, s.18.

4 N. Tosun, "Vicdanı Olanlara: Vicdan Sizlar", Dergâh, S.322, s.9. 
an içinde yaşanan hâdisenin tarihsel, sosyal, psikolojik ve bireysel boyutlarıyla kavranması mümkün kılınmıştır. Hikâyenin dil ve anlatım üslubu okuyucuyu, 15 Temmuz'un "çabuk kabullenilebilir gerçekler" 'ine yöneltir. T1pk1 "ünsüz, gönüllü, halk" tan olan ama adı dahi dillendirilmeyen "Gece" nin kahraman/lar/1 gibi.

\section{"Gece"}

15 Temmuz' da yaşananlar bir nevi turnusol kağıdı etkisi yarattı. Türkiye'deki toplumsal yapıyı oluşturan unsurlar arasındaki farklılığı ortaya koyan, kimin hangi görüş ve tarafa yakın durduğunu netleştiren, seçip ayırıcı bir turnusol kağıdı oldu. Yalnızca bir darbe teşebbüsü olmanın ötesinde büyük bir yıkım ve işgali hedefleyen eylemler silsilesi ile örülen o gecenin, aslında nasıl bir vatan savunması anlamı taşıdığını Güray Süngü’nün “Gece” sinden okumak mümkündür.

“ 'Bağımsız' Türkiye'nin 20. Yüzy1l boyunca fiiliyatta bir tür yarı-yanaşma devlet olarak var olduğunu söylemek, onurumuza dokunsa da, hakikate yakındır. Fakat özellikle son 30 yıldaki iktisadî performansını uluslararası ilişkilerine yansıtmaya başlayınca, Soğuk Savaş tarzı yanaşmalığa artık razı olmadığını göstermiş oldu." 15 Temmuz'da ise Türkiye'nin bu iradî duruşunun mukavemeti ölçüldü. ${ }^{7}$ Turnusol kağıdı etkisi bu noktada kendisini gösterir.

Tarihi Osmanlı Devleti'nin son yüzyılına kadar uzatılabilecek bir realite olan, halk ve bürokrasi(yönetici elit) arasındaki zihin ve değerler dünyası ayrışması, halen varlığını sürdüren yakıcı bir gerçekliktir. Türkiye Cumhuriyeti bu ayrışma nedeniyle tarihi boyunca birçok darbe ile sarsıldı. Yönetici yapının tercihleri onu, halkından dolayısıyla halkının tasavvur ve değerler dünyasından koparttı.

Sezai Karakoç'un alegorik anlatımından hareketle izah edersek, karşıtlığın bir tarafında duran bürokratik yapı veya yönetici elitler, "Bay Yabancı"8 nın

$5 \quad$ N. Tosun, a.g.m., s.9.

6 "Küresel sistemde iktisadî, siyasî ve askerî bakımlardan güçlü bir devletin etkin denetimi altında olan devletlere 'client state' deniliyor. Türkçeye en iyi yanaşma devlet olarak tercüme edilebilecek olan bu siyasî organizasyon, kendi içinde uydu devlet (satellite state), kukla devlet (puppet state) gibi alt türlere de ayrılabiliyor.” Mustafa Özel, “15 Temmuz’un Dünyaya Mesaj1: Türkiye Yanaşma Devlet Olmayacak”, Üsküdar, S. 3, s. 25.

7 M. Özel, a.g.m., s. 25.

8 Sezai Karakoç, “Ötesini Söylemeyeceğim”, Şiirler III Şahdamar/Körfez/Sesler, Diriliş Yayınları, İstanbul 1990, s. 62.

Karakoç şiirinde, “... Kirli çamaşırları tahta döşemelerin/Üzerinde bırakmamanızı yalvararak isteyeceğim/Yalvararak isteyeceğim diyorum/Siz bilmezsiniz size anlatmak da istemem/Kardeşim Ali gömleğinizi mutlaka giyecektir ..." demiştir. Karakoç'un "kirli çamaşır" ve "gömlek" imgeleriyle işaret ettiği yabancının tasavvur ve değerler dünyasının, yerli unsurlar tarafindan benimsenmesi ve yaşatılması tehlikesi Türkiye özelinde vuku bulmuştur. Kuruluşundan bugüne değin yaşanan çatışma alanları, bu ayrışma zemini üzerinde gerçekleşmiş ve sosyal, siyasal ve psikolojik yıkımlarla sonuçlanmıştır. 
gömleğini giyen kardeş "Ali”’9 karakterine karş11ık gelirler. Kurucu unsurlar olarak bu ekip, askerî, siyasî ve ekonomik gücü sürekli ellerinde bulundurur ve bu gücü "Bay Yabancı"10 adına, kendisi gibi yaşamayanlar üzerinde kullanırlar.

"Kemal Tahir'in nefis ifadesini ödünç alırsak, yanaşma zihniyetli insanlarda yerli olma melekesi yoktur." ${ }^{11}$ Bu sebepten, milli mücadele döneminde ülkeyi işgalden kurtarırken maddi ve manevi tüm varı ile mücadele eden halkı, ya kendisi gibi olmak - yerliliğe uzak, yabancıya yakın; yersiz - yahut da hâkimiyetine boyun eğmek seçenekleri arasında zor bir tercih yapmakla karşı karşıya bıraktılar. Hem yerli olamadılar, hem yerliliği aşağıladılar hem de kimliğini yerlilik üzerinden tanımlayan halka karş1 zor kullandılar. "Ulusçu elit"12 yahut bazı "Ali"” ler "Bay Yabancı"" 14 nın gömleğini giymek konusunda istekli olmuşlarsa da nitekim halkın büyük çoğunluğu buna yanaşmadı.

“'Bu ulusçu elit, .. ülkeyi ancak 'Batı'ya hizmet teklif etmekle' koruyabileceklerine inand 1 ve her on y1lda bir 'haddini aşan' millî iradeye darbe indirdi." 15 Çeşitli suretlere bürünmüş ve ulusçu, yönetici elit eliyle gerçekleşmiş darbelere maruz kalındı. Bu nedenle darbe kelimesinin, siyasî ve askerî terminolojideki karşılıklarının dışında, bireysel ve psikolojik açıdan Türk toplumunu derinden etkileyen hadiseler bütününe karşılık geldiğini de ifade etmek gerekir.

Tüm bu, darbelerle yoğrulmuş sosyal ve bireysel ruh halleri içinde halk, geçmişin aciz kalışları karşısındaki pişmanlıklarını da biriktire biriktire 15 Temmuz gecesine erişti. Belki tam da bu sebeple Güray Süngü’nün “Gece"si "bir vatan savunması" anlatmaya başlandığı noktada tamamlanır. Zira bütün mesele bir vatan savunması ile karşı karşıya olunduğunun farkına varıp bu savunmaya cesaret edebilmek noktasında başlar ve dügümlenir. Bu fark ediş, uyanış ve gösterilen irade 15 Temmuz gecesi olanlar içinden en kıymetli olan ve fark yaratanıdır. Çünkü "Gece" nin kahramanının da anlattığ 1 üzere, 15 Temmuz'a kadar dedeler ve babalardan dinlenen bir darbe ve yenilgi anlatısı sürmektedir. 15 Temmuz "Gece"si insanların önünde iki seçenek belirmiştir. Ya kendileri de oğullarına bir darbe anlatacaklardır. Ya da bir darbe değil, bir vatan savunması anlatacaklardır.

"Gece", yapısı ve anlatım tekniğindeki özgün tercihler göz önüne alındığında, 15 Temmuz ardından yazılmış birçok hikâyeden farklıdır. Darbe teşebbüsü sonrası yazılan birçok hikâye, anı veya tanıklık temelli metinlerdir. Çoğu, Milli Mücadele yıllarında yazılan hikâyelere benzer. Bu hikâyeler, yazarlarının tanık-

9 S. Karakoç, a.g.ş., s. 62.

10 S. Karakoç, a.g.ş., s. 62.

11 M. Özel, a.g.m., s. 26.

12 M. Özel, "Paralel Eylemin Romanı", Dergâh, S. 319, s. 11

13 S. Karakoç, a.g.s., s. 62.

14 S. Karakoç, a.g.s., s. 62.

15 . M. Özel, a.g.m., s.11. 
lıkları veya bizzat yaşadıkları ekseninde yazılmışlardı. 20. yüzyılın ilk evresindeki olağanüstü şartlarda yazılan hikâyeler için yapılan, "sanattan biraz yoksun ama samimiyeti yüksek"16 tespiti, 15 Temmuz sonrasında yazılan birçok hikâye için de yapılabilir.

"Gece" nin benzer temalı diğer hikâyelerden en belirgin farkı öncelikle bir kurgusunun olmasıdır. Süngü okuyucusunu, neyi, ne kadar ve nasıl yazacağı konusunda kararlı ve elde edeceği etkiyi hesap etmiş bir yazar stratejisi ile karşılar. Buna rağmen onca tanıklık hikâyesi arasında okuma yaparken "Gece" de ilk olarak bir tanıklık hikâyesi izlenimi veriyor olabilir. Zira birçok 15 Temmuz hikâyesi gibi bu hikâyenin de, o gece yaşadıklarının ilk anlarını aktaran bir kahramanı var. Ne var ki yazarın hadiseleri anlatırken kullandığı ironik dil ve çizdiği karakterin öne çıkan özellikleri fark edildiğinde hikâyedeki kurgu ve kurgunun parlattı̆g 1 anlam tebarüz etmektedir.

Necip Tosun, Süngü'nün yazış tarzını değerlendirirken yazarın ironi ile örülmüş üslûbuna özellikle vurgu yapar. Tosun'a göre Süngü’nün eserleri acıklı olayları neşeli anlatmayı başaran nadir metinlerdendir. "17 "Gece"” de de hâkim bir nitelik olarak ironiyi saptamak mümkün. Hikâye kahramanının dilindeki argo ifadeler, bir şey söyleyip aslında aksini kasteden cümleler ve "beynime bir şaplak indi” gibi alışılagelmiş imajları dönüştürüp kullanarak oluşturduğu, gülümsetirken etkileyen dil sayesinde hikâyenin ironik yapısı oluşur.

İroni dozu yanında Süngü'nün toplumsal meseleler ve edebiyat arasında kurduğu denge de hikâyesinin kurgusuna eşlik eden önemli bir niteliktir. Güray Süngü, memleket meselelerini, insanın bireyselleşme macerasını ve kendi kendisiyle yüzleşmesini öyküleştirirken, 'mesele' ve 'yazın' arasındaki tehlikeli ilişkiyi iyi hesap eden bir tutumla hareket etmektedir. Çünkü bir propaganda diline yaslandığında anlatım, estetik gereklerden yoksundur. Mesajı dolaysızdır ve şablonlara teslim olmuştur. Tipler yapmacıktır ve inandırıcı değildir. ${ }^{18}$ Süngü bu tehlikenin farkında bir yazardır. Bu sayede "Gece" yi kurarken bu hassasiyet noktasını göz ardı etmeden, hamasete kapılmayan bir paylaşım gerçekleştirebilmiş olur.

Hikâyenin sağlam kurgusuna eşlik eden bir diğer niteliği, kahramanının özellikleridir. Kahraman, adı anılmayan - 15 Temmuz'un tüm isimsiz kahramanları gibi - ünsüz, gönüllü ve halktan biridir. Çekirdek çitleyen, Survivor izleyen ve izlerken gönüllüleri tutan sıradan bir şahsiyettir. Güray Süngü'nün hikâye boyunca kendi dilinden konuşturduğu kahramanın kelimeleriyle de beslenen özellikleri, bir yap-bozun parçaları gibi bir araya getirildiğinde, ortaya bir "göbeğini kaşıyan

16 Ali Sürmelioğlu, "Gün Olur Asra Bedel Yahut Kalem Odur Vatana Feda”, Karabatak, S.28, s.60.

17 Necip Tosun, "Vicdanı Olanlara: Vicdan Sizlar", Dergâh, S.322, s. 9.

18 Necip Tosun, a.g.m., s.9. 
adam"19 profili çıkar. Ve Süngü bu adamı, sıradan, kendi halinde ve iddiasız haliyle devleştirir. Zira kısa öykü metni boyunca kurgulanan söylemleri ile "Gece"nin kahramanı, iradesini güçlü bir biçimde eline alabilmiştir. Böylelikle "göbeğini kaşıyan adam" ${ }^{20}$ ve türevi nitelemelerle aşağılanan o halktan biri olarak "Gece" nin kahramanı için kullanılan aşağılayıcı imajlar, tıpkı bir bumerang gibi döner ve kahramanın "kabuğunu kırar" 2 . Güçlü bir tehlike olan darbe teşebbüsünü dahi gögüsleyebilecek bir irade ile "Gece"nin kahramanı yeniden doğar.

Güray Süngü'nün tipik hikâye kahramanlarına benzeyen "Gece" nin kahramanı, yazarın diğer hikâyelerinde de olduğu gibi kendi üslûbunda konuşur. $\mathrm{Bu}$, Süngü'nün hikâyelerinde tercih ettiği genel bir yöntemdir. Çocukluğunun geçtiği Suriçi'nin insanlarını ve mekânlarını yazar çoğunlukla Süngü ve metinlerini oraların havası ve sade gündelik dili ile örer. Bir röportajında "Suriçi'ndeydik, oranın güzelliklerine göre donanmış olduk."22 der. "Kadırga, Suriçi, mahalleler, Kapalıçarşı, tuhaf insanlar, yoksulluk, derme çatmalık, bunları bir yana koyup, sadece okulla, sadece doğru denen şeylerle, sadece size öğretilenlerle, sadece kitaplarda okuduklarınızla şekillenemiyorsunuz.”23 İfadelerinde de görüldüğü üze-

19 Bekir Coşkun'un 03.05.2007 tarihinde Hürriyet gazetesinde yayınlanan köşe yazsının başlığıdır "Göbeğini kaşıyan adam...". Yazının içinde, "Gece”deki kahraman gibi yaşayan ama Coşkun'un bu özellikleriyle alay ettiği bir prototip anlatılır. 2000'li yılların başından itibaren net bir biçimde iradesini eline alan bir halk kesimini, görgüsüzlük, eğitimsizlik, kültürsüzlük gibi aşağılamalar eşliğinde çizer Coşkun. http://www.hurriyet.com.tr/gobegini-kasiyan-adam-6449176

20 Bekir coşkun, a.g.m.

21 '50 kuşağı hikâye yazarlarının özgünlüklerini ve kendilerinden evvelki edebiyât neslinden ayırıcı özelliklerini nitelemek için Jale Özata Dirlikyapan'ın kullandığı ifadenin tam hali, “Kabuğunu Kıran Hikâye" dir. (Bu hususta bkz. Jale Özata Dirlikyapan, Kabuğunu Kıran Hikâye Türk Öykücülüğünde 1950 Kuşă̆g, Metis Yayınları, İstanbul 2013.) Bir önceki edebiyât kuşağına nispetle "yenilikçi” diye nitelendirilen bu yazarlar varoluşçuluk, gerçeküstücülük gibi dönemin Batı düşünce dünyasına hâkim olan fikrî akımlardan etkilenmişlerdir. Bireyin iç dünyasını daha derinlikli ortaya koyan, imgeler, benzetmeler, farklı zaman kullanımları ve mekân soyutlamalarına başvuran '50 kuşağı yazarları, zaman zaman "bunalım edebiyâtı" yapmak, kapalı ve anlaşılmaz yazmakla da eleştirilmişlerdir. (Jale Özata Dirlikyapan, a.g.m., s. 14.) Yazımızda "Gece" nin (Güray Süngü, "Gece”, İtibar, S.59, s.) kahramanı ve temsil ettiği halk için kabuğunu kırmak ifadesini kullanmamız ile '50 kuşağı yazarlarının kabuğunu kırması hali arasında ironik bir karşıtlık ilişkisi söz konusudur. Halktan kopuk, yerellikten beslenmeyen ve hatta ona karşıt bir hayatı önceleyen bir söylemin sürdüğü bir kısım '50 kuşağı hikâyelerindekinin aksine "Gece" nin (Güray Süngü, a.g.m., s. ) kahramanları kabuğunu tam anlamıyla kırmış bir kuşağın temsilcileri oldular. Öz değerleri ve kendi sıradanlıklarıyla tüm zorbalıklar karşısında hem kendilerini hem de kendilerinden evvelki nesilleri esir alan korku kabuklarını kırmış olmalarıyla ele aldığımız hikâyeye konu oldular. Bu nedenle '50 kuşağı için kullanılan mezkûr niteleme ve ardında yatan perspektif penceresinden bakarak "Gece"nin kahramanının özellikleri daha da netleşebilecektir.

22 Ali Ayçil, a.g.m., s. 16.

23 “Her yazar, Yazmak İstediği O Büyük Eserini Yazamadan Ölür”, Temmuz , S.4, s. 43. 
re Süngü, içinde büyüdüğü ve yaşadığı, iyi bildiği hayatları anlatmayı tercih eden bir yazardır. "Gece" nin kahramanı da sanki bu semtlerin adamı olarak belirir.

Hikâye kahramanının argo ifadeleri gündelik dilinin bir parçasıdır. Ayrıca o, etkin bir televizyon izleyicisidir de. Bunu, hikâyenin bütününe hâkim olan zaman kiplerinin, anlatılanları geniş zamana yaymasından çıkarmak mümkündür. Tüm bu özellikleriyle beraber, televizyon izlerken dahi iradesine sahip çıkan bir özelliği vardır. Küçük dünyası içinde izlediği yarışmada dahi ünlüleri değil gönüllüleri tutan, tercihini, her firsat bulduğunda, halktan yana kullanan bir adamdır. Gönüllüleri tutmasının ötesinde "ünlülere gicık ol" an da bir karakterdir.

Hikâyenin başında yer alan paragrafta Süngü, kelime ve gramer kullanımındaki tercihleriyle "Gece" nin kahramanını hem "biz" le bütünleştirir hem de o "biz"i halkın ta kendisi kılar. Hikâye, "Çekirdek çitleyip televizyon izliyorduk." cümlesiyle başlar. Bu cümledeki 'biz' zamiri anlatıyı, özelde kahramanın ailesi genelde ise 15 Temmuz'un "vatan savunması" na katılan tüm halkı adına yapılır hale getirir. Böylece kahraman, hikâye boyunca kendinden her bahsettiğinde tüm halktan da bahsetmiş olur.

$\mathrm{Bu}$ ilk cümlede aile rahatı içinde, kendi halinde bir akşamın huzurlu sahnesi çizilir. Cümle, yalınlığı içindeki basit gerçekliği ile okuyucusunu kavrar ve içine alır. Herkes gibiydik, evdeydik, kendi halimizde ve huzur içindeydik vurgusu hissedilir. Ve daha ilk cümlede, 'aile huzuru, huzursuzluk ve huzur arayış1" izleğinin ilk aşaması oluşturulmuş olur. Bu ilk sahnede "Gece" nin kahraman/lar/1 huzurludur.

"Ünlülere gıcık oluyordum, -çünkü ünlülerdi,- gönüllüleri tutuyordum ben." diye sürer hikâye. Daha ikinci cümlede kendini gösteren 'gıcık' olma hali bilinçli olarak ifşa edilir. Bu ifade, kahramanın 'ünlüler'e olan mesafesini net bir biçimde aktarma amacına matuftur. "Gece" nin kahramanı "ünlülere gicık oluyordum" diyerek, ünlüler imgesine karş11ık gelen halktan kopuk, zengin, elit, bürokratik 'beyaz Türkler' ile ünsüzler yani halk yani gönüllüler arasındaki karşıtlığı da ifade etmiş oluyor. Bu karşıtlık ve uzlaşmazlık nedeni ile ünlüleri tutmamakla kalmiyor onlara "gicik" da oluyor.

Ardından gelen cümlelerde adeta "gönüllüler” güzellemesi yer alır. “.. gönüllüleri tutuyordum ben. Daha içli bakıyorlardı. Hanıma diyordum bunu -hanım ünlüleri tutuyordu, çünkü ünlülerdi- hanım gülüyordu bana, ne içlisi be diyordu, traş bunlar. Hayır traş değildiler. Halktılar. Halk ünsüzdü. Öyleydi.” Tüm bu cümlelerde, giyimleri, konuşmaları, yaşamları, tercihleri ve diğer özellikleri ile "göbeğini kaşıyan adam" ${ }^{24}$ ve benzeri hakaretlere maruz bırakılarak ötekileştirilen ${ }^{25}$

24 Bekir Coşkun, a.g.m.

25 Daryush Shayegan'ın Baudrillard üzerinden yaptığı aktarımla açıklarsak, aynılaştırılma karşısında başkalığın isyanı, Baudrillard'dan tam alıntıyla, "başkalığın ani müdahalesi” devreye 
halkın aslında ne denli sahici olduğu vurgulanmak isteniyor. Tüm bu özellikleriyle gönüllüler grubunun, kendi hallerinde, kendileri gibi ve sahici olduklarının altı çiziliyor. "Öyleydi” deniyor. Diğer yandan ise 15 Temmuz darbe teşebbüsünün önlenmesi karşısında bazı insanların, tüm yaşananların yalan, oyun yahut tiyatro olduğu yönündeki ithamlarına da karşı gelinmiş olunuyor. Satır aralarında, bu denli sahici olan, daha içli bakan, "traş" olmayan, aksine "gönüllü" olan insanlar ancak sahici işler başarırlar iması yer alıyor.

Diğer yandan “Gece” nin kahramanı 'ünsüz' oluşuyla, küçük/sıradan insan niteliğiyle "Gogol'un Palto'sundan çıkmış"26 gibidir. Ne var ki "Palto"nun Akaki Akakiyeviç'ini "Gece" nin kahramanından ayıran büyük bir fark vardır. Süngü'nün kahramanı iradesine her zeminde sahip çıkan bir küçük insandır. Bu özelliğiyle bir Dede Korkut kahramanına dönüşür. Tıpkı bir destan kahramanı gibi oğluna anlatacak kahramanlık hikâyelerinin öznesidir artık. Buna rağmen ne bir destanın süper kahramanı gibi olağanüstü ne de Akaki kadar pasif ve çaresizdir. Her iki prototipi de aşan yalnızca kendisine benzeyen bir prototip; halktır. "Halk ünsüzdü. Öyleydi."

"Gece" bu ilk paragrafın ardından huzursuzluk izleğinde ilerlemeye başlar. Çekirdek çitleyip televizyon izleyen bu insanları reklamlar gerçek dünyaya çă̆ırır birden. "Neyse çekirdek çitliyorduk, son mücadele başlayacaktı, heyecanlıydım, reklama girdi, hayın acun".

Güray Süngü hikâyelerinin temel anlatım biçimlerinden biri de, "kelimenin çağrışımlarıyla oluşan parlak buluşlar" ${ }^{27}$ eşliğinde okuyucuyu etkilemesidir. "Hayın acun" ifadesi bu tekniğin somut örneklerinden biridir. Hikâyede adına yer verilmese de, kahramanın, popüler bir televizyon yapımcısı olan Acun Ilıcalı'nın "Survivor" adlı yarışmasını takip ettiği anlaşılıyor. Bu nedenle de izleme sürerken programın en heyecanlı noktasında reklama giden program yapımcısına sitem edilen bir cümle geliyor. İlk bakışta "hayın acun" derken mezkûr popüler

girmiştir. (Ayrıntılı bilgi için bkz. D.Shayegan, “Ötekinin İsyanı”, Melez Bilinç, Metis Yayınları, İstanbul 2014, s. 29-35.) Shayegan, Baudrillard'ın Borges'in "Aynadaki Hayvanat" adlı öyküsünden yaptığı alıntıya gönderme yapar. Borges, "aynının zorbalığının baskısına uğramış olduğu için intikamını daha da acı alan bastırılmış başkalığı" anlatır öyküsünde. Türkiye Cumhuriyeti özelinde konuşursak, 15 Temmuz'a gelene kadar farklılıklarıyla -dini, siyasi, kültürel ve geleneksel- kabul edilmeyerek ötekileştirilen halk ani bir müdahale ile hakkını geri almıştır. Shayegan, "Aynadaki Hayvanat"1n sunduğu sahnenin korkunçluğundan ve dolayısıyla Baudrillard'ın bunu bir korku imgesi olarak yarattığından bahseder.

26 Dostoyevski'ye atfedilen bu söz aslında Gogol'un modern öykünün kurucusu olma niteliğine atfen söylenmektedir. Zira Gogol "Palto" isimli öyküsünden başlayarak küçük/sıradan insanları öykü sanatına ilk kez sokmuştur. Bu noktadan öncesinde sadece üstün insan, kahraman karakterler anlatılmaya değer görülüyordu. İlk kez Gogol bir prototip olarak sıradan, küçük insanı öyküsüne karakter olarak aldı. (Bu hususta bkz. Necip Tosun, "Modern Öykünün Serüveni”, Modern Öykü Kuramı, Büyüyen Ay Yayınları, İstanbul 2014, s. 13-33.)

27 Necip Tosun, "Vicdanı Olanlara: Vicdan Sizlar", Dergâh, S. 322, s. 9. 
karakterden bahsediliyor. Üstelik bu söyleyişte tatlı bir muziplik de var. Hem kızıyor hem seviyor gibi bir ifade söz konusu "hayın acun" da.

Bununla beraber 'acun' kelimesinin ilk harfinin küçük yazılmış olması dikkate alındığında kelimenin sözlük anlamı ile bir başka çağrışım oluşturulmak istendiği fark edilir. Sözlükte "evren/dünya” anlamına gelen 'acun', 'hayın' kelimesiyle beraber kullanıldığında başka bir anlam belirir. Reklamların girmesiyle, televizyonun sunduğu konforlu, sorumluluktan uzak ve rehavet yaratan atmosferden uyanmak durumunda kalan "Gece" nin kahramanı, dünyanın bu gel-gitli halleri karşısında sitemkâr bir tavra bürünür.

Tam da bu noktada hikâye yeni bir sahne açar. "Gece" nin karakteri reklamların girdiği kanaldan hemen kaçar. Başka kanallarda kaçan huzurunu tekrar aramaya çalışır. "Kumandayı aldım elime, zapladım. Boş beleş. Zapladım. Tırı vırı. Zapladım." Sonra birden karşısına, huzurunu daha fazla kaçıran bir sahne çıkar. "Oha dedim, köprüyü gösteriyordu televizyon. Bu ne lan dedim. Köprü tek taraftan trafiğe kapatılmıştı. Oha... tanklar ve askerler tarafindan kapatılmıştı." Karakter olağanüstü bir şeyle karşı karşıya olduğunun farkına varır. Bunu da tam kendi üslûbunda ifade eder. Argo ifadeler, kısa ve öz cümleler okuyucuyu da hadisenin sahiciliğine çekiverir.

"Gece" nin kahramanının iç muhasebesi başlar. "Hemen anladım. Terör istihbaratı vardı. Kesin. Hemen TRT Habere zipladım. Hava durumu sunuyordu devlet kanalı. Biraz bekledim. Değişmedi. Öbür kanala baktım. Bayağı ciddi ciddi tankları gösteriyordu uzaktan, ne olduğu belli değil diyorlar tartışıyorlar anlamaya çalışıyorlardı. Trt habere baktım tekrar. Trt'de bi cacık yoktu.” 15 Temmuz gecesi malum olağanüstü durumla televizyon aracılığıyla karşılaşan bir çok insanın düşündüğü biçimde düşünüyor "Gece" nin kahramanı da. O sırada ekranlarda, köprünün Anadolu yakasından Avrupa yakasına geçiş güzergâhında, gişelerden sonraki alanda durmuş bekleyen iki askerî kamyon ve tankların önüne dizilmiş bir grup silahlı asker görüntüsü vardır. Avrupa yakasından Anadolu yakasına araçların geçişi sürmektedir. "Gece" nin kahramanı bu olağanüstü durumu ilk olarak bir terör eylemine karşı askerin aldığ önlem olarak algılar. Gerçeği en kısa ve net biçimde öğrenebilmek adına "TRT Haber" e yönelir. Bu bölümde 'TRT Haber ifadesi önce büyük harflerle yazılıyor. Sonraki iki kullanımında ise ' $T$ ' dışındaki tüm harfler küçük tercih ediliyor. Süngü'nün gramer ve imlayı anlamı vurgulamak için kullanışına bir örnek de bu noktada kendini gösterir. Zira "Gece"nin kahramanı karşılaştığı olağan dışı hadise hakkında en sahih bilgiyi bulabileceğine inandığı için hemen devletin haber kanalını açar. Çünkü, hikâyenin ilerleyen kısmında ifade edeceği üzere, bu olağan dış1lığ ancak devletin sürekli haber sunan kanalından tatmin edici bir cevapla çözebileceğini düşünür. Ne var ki devletin kanalı hava durumu haberinde donmuş kalmıştır. Havadan sudan bahseder adeta. Bundan dolayı kahramanın gözünde devletin kanalı yavaş yavaş bi- 
ricik konumunu kaybeder. Süngü, bu durumu imlayı etkin bir biçimde kullanarak vurgular. TRT Haber' in 'Türkiye'yi temsil eden ' $T$ ' harfi dişındaki diğer harfleri yavaş yavaş küçülmeye başlar.

"Gece" nin huzurun kaçışı izleğinin en sarsıcı sahnesine zemin olarak köprü görüntüsünün seçilmiş olması da bir anlam ifade eder. 15 Temmuz'a dair gelen ilk görüntüler arasında en sembolik olanlarından biri olmasına rağmen köprünün tutulmuş olması hadisesi, hikâye içinde özel olarak seçilmiş ve birçok anlamı beraber barındıran bir imaj halini alır.

“15 Temmuz 2016 akşamı girişilen darbe kalkışması pek çok gösterenin gösterilenini değiştirmiş, zenginleştirmiş ve yepyeni anlam alanları ilave etmiştir." 28 "Gece" de bu dönüşen ve zenginleşen anlam alanlarından istifade eder. Hikâyede huzursuzluğun ve aynı zamanda uyanışın sahnesi olarak seçilen ilk imajın zemini köprüdür. Söz konusu tercihin sosyolojik ve tarihsel bir bilinçaltına dayandığ 1 söylenebilir. "Köprünün birleştirme özelliği dolayısıyla sağladığı imkân aslında bir özgürlük biçimidir. Köprü, burada kalmak zorunluluğundan kurtulup oraya da gidebilmek hürriyetinin temsilcisidir. ... Köprü hayalin orada, gerçeğin burada kalmasının gerilimini ortadan kaldırır." ${ }^{29} 15$ Temmuz akşamı yapılanlar, tüm bu anlam alanlarıyla sosyal hafizanın güçlü bir parçası olarak köprüyü dolayısıyla özgürlüğü ortadan kaldırma amacına hizmet etmekteydi. "Gece" nin anlam dünyasında da köprü üzerinde yolu kapatmış silahlı askerler imajı, aynı sarsıcı etkiyi yaratmaktadır. Dolayısıyla "Gece"nin kahramanı ilk olarak, bireysel ve toplumsal özgürlüğün elden gidiyor olması tehlikesi karşısında uyanır.

"Çok akıllı bir adam olmasam da anında düşündüm; bu kanal devletin kanalı. Tanklar da devletin malı. Devletin kanalı tankların köprüde olduğunu verirse, neden orda olduğunu da verir. Vermelidir. Bir ihbar var. Bir istihbarat var. Vermezse neden vermez. Bilmiyordur tanklar neden orda, ondan vermez. Nasil bilmez. Beynime bir şaplak indi." "Çok akıllı bir adam olmasam da anında düşündüm”30 diyerek ironik bir dille "Gece" nin kahramanının uyanış hikâyesi örülmeye başlanır. Süngü "Gece"nin kahramanı ve benzeri insanlara yöneltilen ithamlardan birini daha bumerang misali gönderenlere geri firlatmış olur bu ironik yaklaşımıyla. "Çok akıllı bir adam" değildir kahraman ama meseleyi saniyede çözümleyip eyleme geçen de kendisidir. Hadisenin olağan dışılığ sında oldukça analitik bir yaklaşımla meselenin özünü kavrayabilir. Yaşananlar karşısında devlet habersizdir.

"Beynime bir şaplak indi” cümlesi ile farkına varıp uyanışın çarpıcı bir imajla temsil edilmesine geçilir. “Güray Süngü’nün anlatı özelliklerinden biri de tersine 
çevirme, algıyla oynamadır. Bir okur olarak klişeleşmiş bir sloganı, aforizmay1 tersine çevirip okuru kendine getirir." 3115 Temmuz'a kadar ensesine yediği şaplaklar karşısında aciz kalan, her ensesine vurulduğunda ekmeğini elinden b1rakma pozisyonuna razı gelen "Gece" nin kahraman/lar/1, o akşam direk beyne inen "şaplak" ile uyanıp, iradesi, ekmeği ve özgürlüğünü ellerine alırlar. Beyne inen şaplak imajı ile aynı zamanda, 15 Temmuz' da yaşananların hiç beklenmedik olduğu ve ne büyük bir etki yarattığı da vurgulanır. Bu şok etkisi yaratan imaj ardından hikâye, 'aile huzuru, huzursuzluk ve huzur arayışı' izleğinin son kısmına erişir; huzur arayışı.

"Kalktım, kucağımdaki çekirdek tabağı uçtu halıya. Hanım dedim, kalk. Sokağa çıkıyoruz." Çekirdek çitleyen, "göbeğini kaşıyan", televizyon izleyen, çok da ak1llı olmayan adam bugüne kadar ensesine sürekli "şaplak" vuran ellerin, 15 Temmuz'da beynine kadar el uzatması ile uyanır ve harekete geçer. "Gece" nin kahramanı, beyin kelimesinin ifade edebileceği tüm anlam alanlarını, beynin tüm fonksiyonlarını -idrak, muhayyile, akletme, düşünme, karar verme vb.- durdurmaya yönelik bu hamleye dur demenin gerekliliği ile karşı karşıyadır. $\mathrm{O}$ akşam sokakları, meydanları, köprüleri tutanların ülkeyi ve milleti de tutacăğ, tekrar zor kullanacağı açığa çıkmış olur.

"Mesele neydi belli değildi ama neydi belliydi. Devletin kanalı, devletin tankı ve askerinin devletin köprüsünde ne yaptığını bilmiyorsa, bu üç unsurdan biri devletin değildi artık." Süngü'nün "çarpıcı zıtlıklar"32 ile ördüğü cümlesi, meseleyi veciz bir açıklık ile izah etmiş olur. "Mesele neydi belli değildi ama neydi belliydi" derken "Gece" nin kahramanı devletin aciz kaldığı noktada meselenin çözücü öznesi oluverir. O andan itibaren farkına varılır ki meydanda, sokakta "kim varsa ülke onundur." 33

"Dedem oğluna bir darbe anlatırd1. Babam da oğlu olan bana bir darbe anlatırdı. O halde önümde iki seçenek vardı. Ben de oğluma bir darbe anlatacaktım. Ya da ben oğluma bir darbe değil, bir vatan savunması anlatacaktım. İşte oğlum, o gün her şey böyle başladı." Doğu medeniyeti için hikâye ile aktarmak çok önemlidir. Hikâyenin bir bellek işlevi bulunur. Yaşananları, kutsal görülen tecrübeyi anıtlaştırıp aktarmak için hikâye en uygun araç olarak kabul edilegelmiştir. "Gece" nin kahramanı da bu geleneğe bağlı, Doğu'nun edebî, kültürel ve sanatsal temayüllerini yaşatan bir kimlik olarak çizilir. Tıpk1, "çok değer verdikleri bilgileri, ögütleri, hikmetleri iletmede; tecrübeleri, birikimleri aktarmada hikâyeye ihtiyaç"34 duyan ataları gibi 15 Temmuz'da yaşananları ve ardından gelen süreci

31 Necip Tosun, a.g.m., s. 9.

32 Necip Tosun, a.g.m., s. 9.

33 Dursun Ali Tökel, a.g.m., s. 82.

34 Necip Tosun, “Sunuş”, Modern Öykü Kuramı, Büyüyen Ay Yayınları, İstanbul 2014, s. 7. 
oğluna hikâye eder. Klâsik Türk edebiyatı dönemine ait destanlarda da hâkim olan oğula aktarma imaj1 "Gece"de tekrar edilir. Böylelikle yaşananların, "çöp gibi sürüklenme ihtimaline karşı kayıt altına almaya değer" 35 birer hikâye olduğu yaklaşımına uygun hareket edilmiş de olur.

"Gece" öyle bir noktada tamamlanır ki, bu konuda söylenecek daha çok söz, anlatacak daha çok hikâye olduğu sezdirilir. Uyanış ve harekete geçiş haline tanıklık edilen kahramanın daha neler yapmış ve yaşamış olabileceğine dair merak unsuru ile bağlanır hikâye.

35 Yıldız Ramazanoğlu, “Olumlu Hikâyemiz”, Türk Edebiyatı Hikâye Özel Sayısı S. 514, s. 29. 


\section{Sonuç}

"Gece” nin, Güray Süngü’nün sanatkârane dokunuşları ile ördüğü kısa ama veciz bir hikâye olduğu tespiti yapılabilir. 15 Temmuz darbe girişiminin, halkın - "Gece"nin diliyle söylersek gönüllüler ve ünsüzler topluluğunun - direnişi ile başarı elde edemeyişi gerçeğinin nasıl bir uyanış, diriliş ardından hayata geçtiğini öz bir surette aktarmıştır. Hikâyenin 'ünlüler-gönüllüler' karşıtlığg zemininde kurgulanış ve halk ile kurucu elit, yerlilik ile yabancılık arasında süregelen karşıtlıkların geldiği son noktayı izah ediş tarzı hem ironik, bir o kadar da sahicidir.

"Sanat söylemin ruhudur. Ruh yaşar." 36 yaklaşımı hikâyenin tümüne hâkim gibidir. 15 Temmuz ardından ülke ve bölge olarak içinde akmaya başlanan süreci anlamlandıran yerli, millî ve dinî sloganlar ile vurgulanan - örneğin "okçular tepesi boş değil" ${ }^{37}$-, geçmiş nesillerin düştükleri hatalara düşülmediği tespiti ve düşülmeme yönündeki kararlılık, hikâyenin son paragrafında vurucu bir biçimde ebedîleştirilir.

36 Fatih And1, “15 Temmuz’u Anlatmak”, Üsküdar, S. 3, s.21.

37 Geçmişe gönderilmiş ve aynı zamanda geleceğin duvarına asılan bir telgraf cümlesi gibi duran bu söz, 15 Temmuz direnişine eşlik eden diğer bir çok ifade gibi, geçmişin hatalarının tekrar edilmediğinin ve edilmeyeceğinin andı gibidir. Uhud Savaşı esnasında Hz. Muhammed'in (S.A.V.) emri ile sahabeden bir grup, okçu birliği olarak meydana hâkim bir tepeye konuşlandırılmıştı. Savaş stratejisi gereği akıllıca bir hamle olan bu taktik savaşın yön değiştirdiği bir anda, ganimet toplama telaşına düşen okçuların Hz. Muhammed'in (S.A.V.) emrini unutup tepeyi boş bırakmaları sonucu, boşa çıktı. Sonuçta savaş kaybedildi. 'Okçular tepesi boş değil' sözü, yaşanan hadisenin halk tasavvurunda, hem kökleri Hz. Muhammed (S.A.V.) devrine uzanan bir tarihsel izlek üzerinden anlamlandırıldığını hem de hatalardan ders çıkarıldığını ifadelendirmiş olur. 15 Temmuz ardından, dinî, millî ve kültürel anlamda yerliliğe ait tüm unsurların halk tasavvurunda sahiplenildiği ve bunlar dışında kalan unsurların tümüyle anlamını yitirdiğini gösteren sembol ifadelerden biri olarak durmaktadır. 


\section{Kaynakça}

And1, Fatih, “15 Temmuz'u Anlatmak”, Üsküdar, sayı 3, 2016.

Ayçil, Ali, “Roman İnsanlığın Ortak Dili”, Dergâh, sayı 322, 2016.

Coşkun, Bekir “Göbeğini kaşıyan adam...”. http://www.hurriyet.com.tr/gobegini-kasiyan-adam-6449176

Daşçığlu, Yılmaz, “Köprü Hürriyeti ve Bayrak”, Üsküdar, sayı 3, 2016.

Karakoç, Sezai, "Ötesini Söylemeyeceğim”, Şiirler III Şahdamar/Körfez/ Sesler, İstanbul, Diriliş Yayınları, 1990.

Özata Dirlikyapan, Jale, Kabuğunu Kıran Hikâye Türk Öykücülüğünde 1950 Kuşăğ, İstanbul, Metis Yayınları, 2013.

Özel, Mustafa, “15 Temmuz’un Dünyaya Mesaj1: Türkiye Yanaşma Devlet Olmayacak", Üsküdar, say1 3, 2016.

Özel, Mustafa, "Paralel Eylemin Romanı”, Dergâh, sayı 319, 2016.

Ramazanoğlu, Yıldız, “Olumlu Hikâyemiz”, Türk Edebiyatı Hikâye Özel Saylsl, say1 514, 2016.

Süngü, Güray, “Gece”, İtibar, say1 59, 2016.

Sürmelioğlu, Ali, "Gün Olur Asra Bedel Yahut Kalem Odur Vatana Feda", Karabatak, say1 28, 2016.

Tosun, Necip, “Karakter: Yeni Bir Hayat Teklifi”, Modern Öykü Kuramı, İstanbul, Hece Yayınları, 2014. , "Vicdanı Olanlara: Vicdan Sizlar", Dergâh, sayı 322, 2016

Tökel, Dursun Ali, "Darbeyi Yeni Gösterilenlerle Okumak”, Üsküdar, say1 3, 2016.

"Her Yazar, Yazmak İstediği O Büyük Eserini Yazamadan Ölür", Temmuz, say1 4, 2016. 